\title{
Fragile-X Mental Retardation: Molecular Diagnosis in Argentine Patients
}

\author{
Giliberto Florencia*, Szijan Irene and Ferreiro Veronica \\ Genética y Biología Molecular, Facultad de Farmacia y Bioquímica, Hospital de Clínicas, Universidad de Buenos Aires, \\ Buenos Aires, Argentina
}

Received 27 May 2006, Accepted 28 July 2006

\begin{abstract}
Fragile-X-syndrome (FXS) is the most common type of inherited cognitive impairment. The underlying molecular alteration consists of a CGG-repeat amplification within the FMR-1 gene. The phenotype is only apparent once a threshold in the number of repeats has been exceeded (full mutation). The aim of this study was to characterize the FMR-1 CGG-repeat status in Argentine patients exhibiting mental retardation. A total of 330 blood samples from patients were analyzed by PCR and Southern blot analysis. Initially, DNA from 78 affected individuals were studied by PCR. Since this method is unable to detect high molecular weight alleles, however, we undertook a second approach using the Southern blotting technique to analyze the CGG repeat number and methylation status. Southern blot analysis showed an altered pattern in 14 out of 240 $(6 \%)$ unrelated patients, with half of them presenting a mosaic pattern. Eight out of 17 families (47\%) showed a (suggest deleting highlight). The characteristic FXS pattern was identified in $8 / 17$ families $(47 \%)$, and in 4 of these families $25 \%$ of the individuals presented with a mosaic model. The expansion from pre-mutation to full mutation was shown to occur both at the pre and post zygotic levels. The detection of FXS mutations has allowed us to offer more informed genetic counseling, prenatal diagnosis and reliable patient follow-up.
\end{abstract}

Keywords: Fragile X syndrome, Mental retardation, Microsatellites expansion, Molecular diagnosis

\section{Introduction}

Mental retardation is a very frequent disorder with an incidence of 1 in every 100 new born children (ref). Patients present with a broad range of mental deficiencies, whose

*To whom correspondence should be addressed.

Tel: 54115950 8805; Fax: 541149648296

E-mail: florgiliberto@yahoo.com.ar etiology is almost always unknown. There are more than 100 candidate genes for mental delay that are related to the human $\mathrm{X}$ chromosome. One of the genes is FMR-1 (Fragile Mental Retardation-1), which is responsible for the Fragile-X Syndrome (FXS) and represents $30 \%$ of the mental delays linked to the $\mathrm{X}$ chromosome. FXS is the most common cause of hereditary mental retardation (Merenstein et al.; 1996) and one of the most frequent diseases with a known genetic origin. Numerous studies have found FXS in every ethnic group that has been evaluated, with an incidence of 1 in 4,500 males and 1 in 9,000 females, whereas the actual incidence of at-risk individuals is estimated at 1 in 1,000 for males and 1 in 400 for females (Warren, 2001).

In addition to the mental retardation, which can range from mild to severe, behavioral problems such as hyperactivity, lack of attention, repetitive and disorderly language, and incoherent thought expression are common to both affected males and females.

Cloning of the FMR-1 gene (Xq27.3) (Verkerk et al., 1991) has enabled the discovery of mutations responsible for FXS. The gene spans $38 \mathrm{~Kb}$, contains 17 exons and has a sequence of (CGG)n triplets in the 5' untranslated region of exon 1 (Fig. 1A). It is expressed as $4.8 \mathrm{~Kb}$ mRNA, which undergoes different alternative splicing, and was found in several tissues but mainly in brain and gonads (Hinds et al., 1993; Abitbol et al., 1993). The FMR protein is involved in translation regulation (Corbin et al., 1997; Li et al., 2001; Laggerbauer et al., 2001). The molecular alteration responsible for FXS consists of the CGG repeat amplification, resulting in hypermethylation of a "CpG island" located within the FMR-1 gene promoter. This event is predicted to abrogate gene transcription resulting in loss of the FMR-1 protein. (Kremer et al., 1991; Pieretti et al., 1991; Coffee et al., 1999; Warren, 2001) (Fig. 1B) and was the first example of a new type of genetic alteration referred to as "dynamic mutation" or "unstable DNA" that might arise by meiotic recombination or during DNA replication and repair (Malter et al., 1997; Pearson, 2003).

Three different ranges of (CGG)n have been described: 1 . Normal: the length of the repeat locus varies from 5 to 50 repeats; 2. Premutation or predisposition to disease: 50 to 200 
(A)

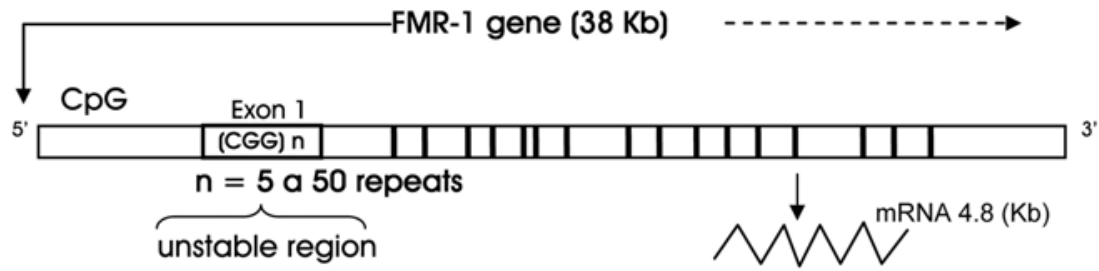

(B)

\section{hypometylated site}

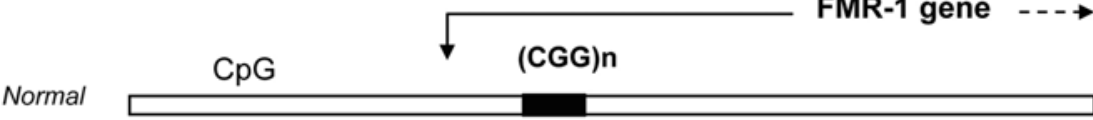

hypometylated site

ר $\bigwedge^{\operatorname{mRNA}(4.8 \mathrm{~Kb})}$

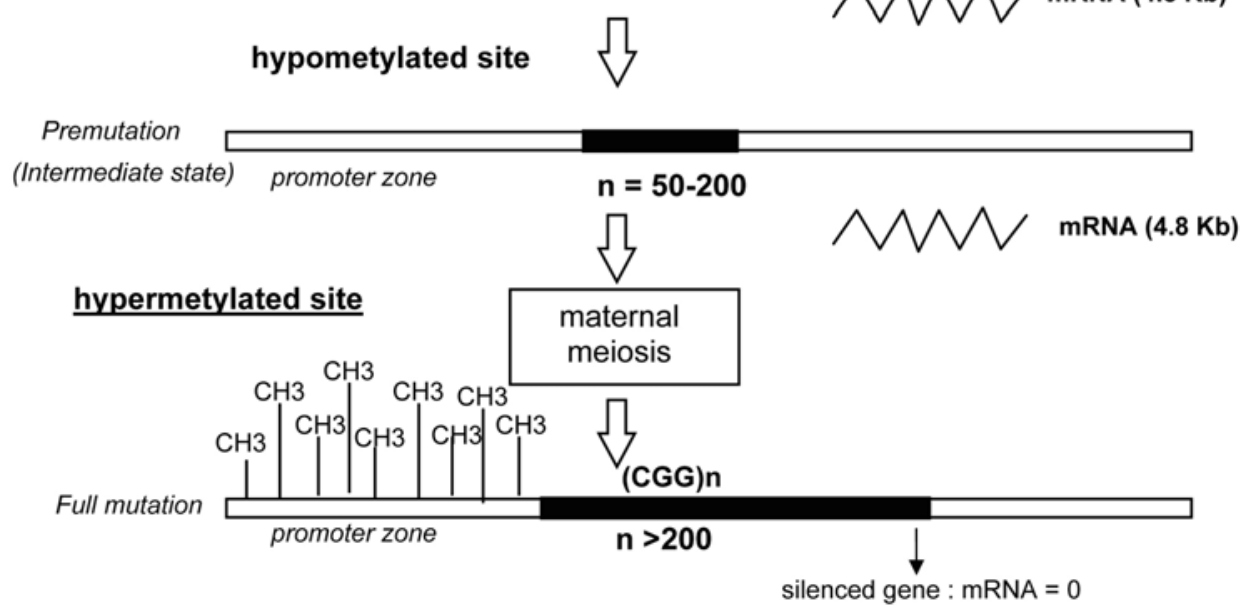

Fig. 1. FMR-1 gene and the molecular mechanism of Fragile $X$ syndrome. (A) Schematic representation of the FMR-1 gene; CpG: CG-repeat island within the promoter; (CGG)n: trinucleotide-repeat sequence in exon 1. (B) Expansion of (CGG)n in different degrees and its effect on the functionality of the gene. Normal and expanded alleles (premutation and full mutation) and also the location of hypo and hypermethylated $\mathrm{CpG}$ islands are indicated.

repeats; 3. Full mutation, the number of triplets may arise from 200 to several thousands. Full mutation is almost always associated with methylation of the promoter region of the gene and correlated gene inactivation (Fig. 1B) (Pieretti, 1991). Males and females carrying a premutation are unaffected. Male carriers are referred to as "normal transmitting males" (Sherman et al., 1985), and they pass on the mutation, relatively unchanged in size, to all of their daughters. These daughters are unaffected, but are at risk of having affected offspring. A premutation is only susceptible to expansion after passage through a female meiosis (Malter et al., 1997; Moutou et al., 1997).

Due to the novel nature of the Fragile X mutation, inheritance is less straightforward than with classic Mendelian traits. While passage through a female meiosis is necessary for a significant trinucleotide repeat expansion, the expansion most likely occurs during early embryonic development. Since expansion is occurring in a multicellular embryo and the extent of expansion may vary from cell to cell, individuals often display somatic heterogeneity in their allele size. Some affected individuals, termed mosaics, exhibit both a premutation and a full mutation in their circulating blood cells. (Dobkin et al., 1996; Allingham-Hawkins et al., 1996; Genc et al., 2000). On the other hand, the premutation is stable during spermatogenesis in males (Reyniers et al., 1999).

The fragile- $X$ syndrome has no cure and the management of affected individuals may be limited to simply maintaining and promoting the abilities attained by these children. Therefore, an early and reliable diagnosis is an important step to enabling a specific treatment for each patient.

The work to be described aimed to improve our understanding of a FXS development mechanism and to implement a useful molecular tool for mutation detection and prenatal diagnosis. We focused, therefore, on characterizing the FMR-1 (CGG)n microsatellite in the Argentine mental retardation population by using PCR and Southern blot analysis, with the objective of providing improved genetic counseling to the families of the mentally challenged patients. 


\section{Materials and Methods}

Patients. Three hundred and thirty individuals (236 males and 94 females) with the clinical diagnosis of Fragile- $X$ syndrome were referred to from various Hospitals in Buenos Aires and other health-centers in Argentina. The diagnosis of FXS was based on classical criteria and included a family history of mental retardation, a mental delay of unknown origin for the patient, clinical characteristics of the syndrome and/or chromosomal fragility at the end of the long arm of an X chromosome.

The research was carried out according to the principles of the Declaration of Helsinki and with informed patient or parental consent.
The institutional review board of the Hospital de Clínicas, Universidad de Buenos Aires, Buenos Aires, Argentina has approved the study.

DNA samples. The peripheral blood was anticoagulated with $0.5 \%$ EDTA by CTAB method (cetyltrimethylammonium bromide), chloroform-isoamil alcohol purification and ethanol precipitation, centrifuged and the cells separated for further analysis.

PCR analysis. DNA samples from 78 patients (57 from males and 21 from females) were amplified by PCR according to the protocol of Hilbert and Sabine (Hilbert and Sabine, 1996). Briefly, $400 \mathrm{ng}$ of

(A) PCR amplification of the CGG-repeats:

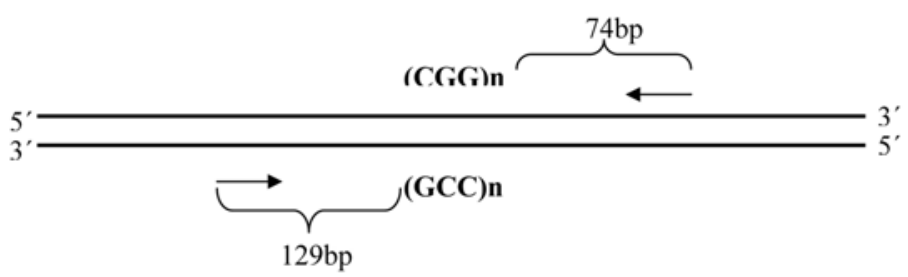

n: $6-54=18-162 b p+203 b p(129+74)=221-365 b p$ Normal

n: $52-193=156-579 b p+203 b p=359-782 b p$ Premutation

$n:>200=>600 b p+203=>800$ bp Full mutation

(B) Southern blot, FMR-1 gene

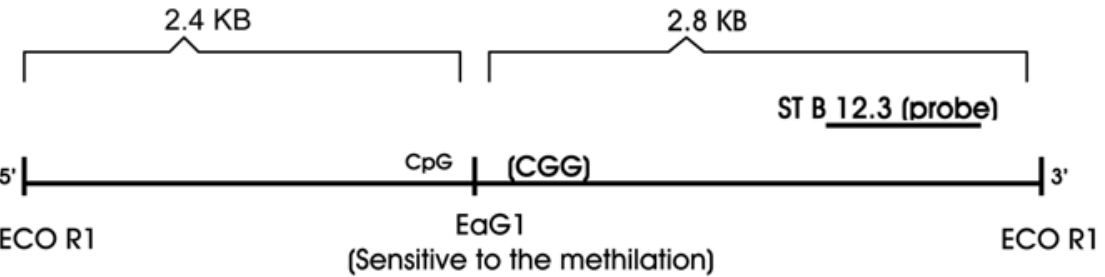

\section{Normal woman}
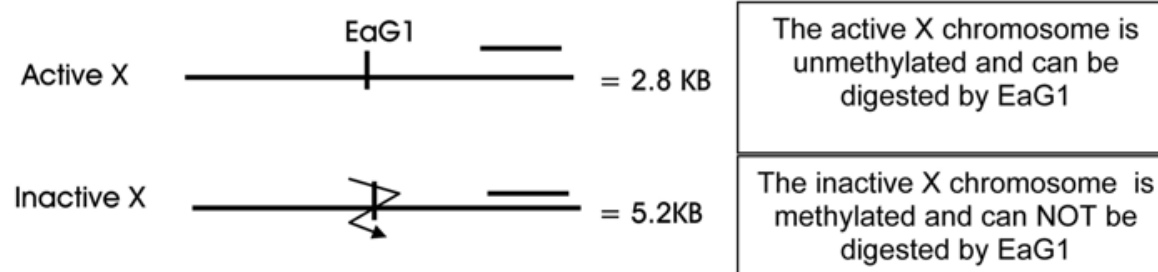

The inactive $\mathrm{X}$ chromosome is methylated and can NOT be digested by EaG1

\section{Normal man}
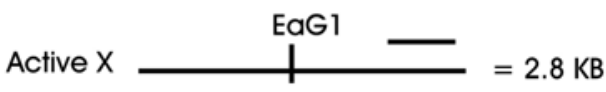

The normal male has one active $\mathrm{X}$ chromosome

Fig. 2. Identification of alleles with normal, premutated and full-mutated (CGG)n repeat sequences by PCR and Southern blot analysis. (A) Molecular weight of PCR-products obtained by amplification of a normal FMR-1 gene and genes at premutation and full mutation (ED - check that this is a correct statement). (B) Molecular weight of the fragments generated by Southern blot analysis from an active and an inactive normal X-chromosome. 
genomic DNA were used in a total volume of $15 \mathrm{~mL}$, containing $300 \mathrm{nM}$ of each primer (forward: 5' GTC AGG CGC TCA GCT CCG TTT 3' and reverse: 5' CTC CAT CTT CTC TTC AGC CCT GCT 3'), $200 \mu \mathrm{M}$ of each dATP- dCTP- dTTP, $50 \mu \mathrm{M}$ of dGTP; $150 \mu \mathrm{M}$ of 7-deaza-dGTP; $10 \%$ of DMSO; $1.5 \mu \mathrm{l}$ of Expand PCR buffer $1 ; 2 \mu \mathrm{Ci}$ of $\alpha{ }^{32} \mathrm{P} \mathrm{dCTP}$; and 0.5 units of Expand ${ }^{\mathrm{TM}}$ long Template enzyme Mix.

DNA was mixed with water and heated at $95^{\circ} \mathrm{C}$ for $5 \mathrm{~min}$. All the components of the PCR mix, except the enzyme, were added and heated again for $5 \mathrm{~min}$ at $95^{\circ} \mathrm{C}$. Subsequently, the enzyme was added and denaturation continued at $95^{\circ} \mathrm{C}$ for $2 \mathrm{~min}$ followed by 30 cycles of denaturation at $95^{\circ} \mathrm{C}$ for $90 \mathrm{sec}$, annealing at $56^{\circ} \mathrm{C}$ for 60 sec and elongation at $72^{\circ} \mathrm{C}$ for $120 \mathrm{sec}$, The final extension was carried out at $72^{\circ} \mathrm{C}$ for $7 \mathrm{~min}$. The PCR products $(2-4 \mu \mathrm{L})$ were mixed with one volume of stop solution ( $95 \%$ formamide, $0.5 \%$ EDTA, $0.05 \%$ bromophenol blue, and $0.05 \%$ xylene cyanol), heated at $95^{\circ} \mathrm{C}$ for $2 \mathrm{~min}$, and electrophoresed on a $5 \%$ polyacrylamide/urea denaturing sequencing gel. Autoradiography of the dried gel was performed at room temperature over 1-3 days.

Southern blot analysis. A total of 285 individuals (199 males and 86 females) were studied, 240 unrelated, and 45 from 17 familial cases. The protocol reported in Oberlé et al., 1991 (Oberlé et al., 1991), was followed with some modifications: $10 \mu \mathrm{g}$ of DNA were digested during $20 \mathrm{~h}$ at $37^{\circ} \mathrm{C}$ with 50 units of EcoRI and 50 units of EagI in a final volume of $300 \mu \mathrm{L}$, including $10 \mathrm{mM}$ pH 7.3 Tris, $100 \mathrm{mM} \mathrm{NaCl}, 20 \mathrm{mM} \mathrm{MgCl}, 2.1 \mathrm{mM}$ DTT and $100 \mu \mathrm{g} / \mathrm{mL}$ BSA. The digested DNA was precipitated with $1 / 10$ volume of $3 \mathrm{M} \mathrm{NaCl}$ and 2 volumes of $100 \%$ ethanol at $-20^{\circ} \mathrm{C}$ over night, centrifuged at $12,000 \mathrm{rpm}$ during $15 \mathrm{~min}$ and resuspended in $20 \mu \mathrm{L}$ of distilled water. Electrophoresis was performed on a $1 \%$ agarose gel over night at $1.7 \mathrm{v} / \mathrm{cm}$, and a molecular weight marker was run in parallel $(2.5 \mathrm{~Kb}$ to $8 \mathrm{~Kb})$. The gel was denatured in $0.25 \mathrm{M} \mathrm{HCl}$ for $10 \mathrm{~min}$, treated with $0.4 \mathrm{~N} \mathrm{NaOH}$ for $10 \mathrm{~min}$ and transferred for 16 to $24 \mathrm{~h}$ to a membrane, which was then washed twice with $2 \times \mathrm{SSC}$ for $5 \mathrm{~min}$ and dried at $80^{\circ} \mathrm{C}$ for $1 \mathrm{~h}$. .An StB 12.3 probe (Oberlé et al., 1991), was radioactively labeled by the Random priming method (ref?). Prehybridization and hybridization were carried out in $50 \%$ formamide, $5 \times \mathrm{SSPE}, 5 \times$ Denhardt, $1 \% \mathrm{SDS}$ and $200 \mathrm{mg} /$ $\mathrm{mL}$ of salmon sperm denatured DNA $\left(10 \mathrm{~min}\right.$ at $\left.90^{\circ}\right)$ at $42^{\circ} \mathrm{C}$ for 2 and $16 \mathrm{~h}$ respectively, followed by the following washes: $2 \times \mathrm{SSC}$, $0.1 \% \mathrm{SDS}$ for $5 \mathrm{~min}$ at room temperature, once; $2 \times \mathrm{SSC}, 0.1 \%$ SDS for $15 \mathrm{~min}$ at $60^{\circ} \mathrm{C}$, three times; $0.5 \times \mathrm{SSC}, 0.1 \%$ SDS for 20 $\min$ at $60^{\circ} \mathrm{C}$, three times.

The size of the fragments obtained by the PCR and Southern blot analyses and the classification of the alleles according to the degree of mutation detected in males and females are shown in Figures 2 and $3 \mathrm{~A}$, and Table 1.

\section{Results}

PCR analysis of 78 patients ( 21 females and 57 males) with clinical features of FXS yielded the following results: i) Presence of two alleles of normal size in 4 females (19\%); ii) One normal allele $(<365 \mathrm{pb})$ and the second premutated (450 bp) in 4 other females (19\%); iii) One normal size band

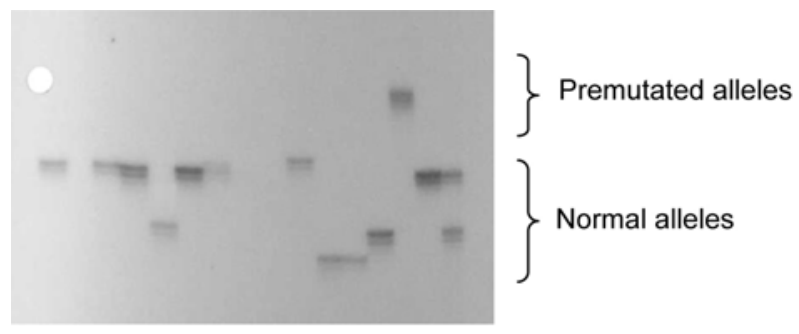

(A)

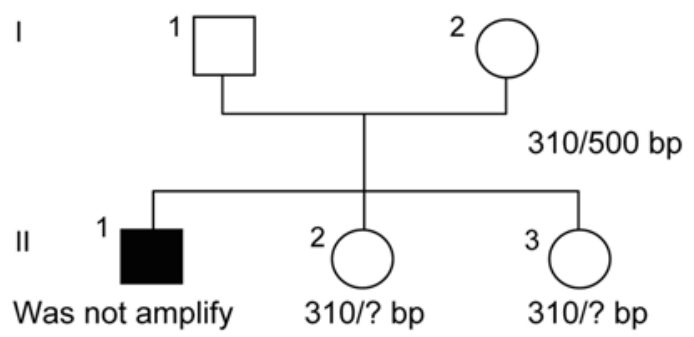

(B)

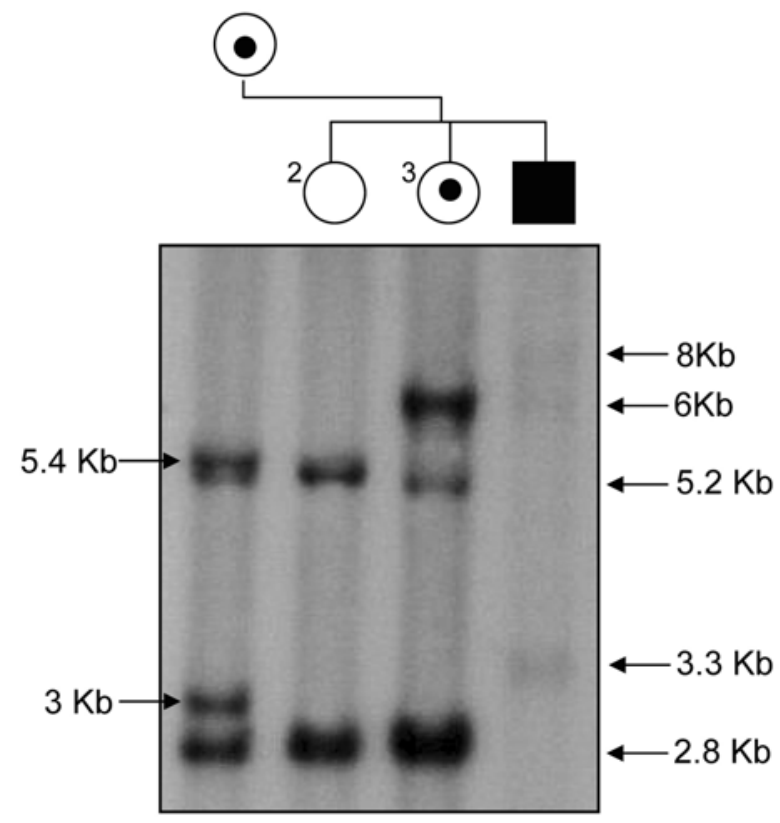

(C)

Fig. 3. PCR-band patterns obtained from different individuals and the analysis of an affected family. (A) Band-pattern of normal and premutated FMR-1 alleles obtained by autoradiography of the PCR-products. (B) Pedigree of Family I showing the molecular weight of PCR-products corresponding to normal and premutated alleles. (C) Band-patterns obtained by autoradiography of Southern blot analysis showing the presence of normal, premutated and full mutated alleles in different members of family I.

in 7 females (33\%); iv) DNA samples were not amplified in 6 females $(29 \%)$; v) One normal allele in 35 males (61\%); vi) One premutated allele in 2 males (4\%); vii) DNA samples were not amplified in 20 males (35\%).

In cases where DNA samples were not amplified, probably 
Table 1. Fragile-X Patients and Families with an altered band-pattern determined by Southern blot analysis

\begin{tabular}{|c|c|c|c|}
\hline \multicolumn{2}{|c|}{ Individuals } & Bands (Kb)/Mutation & Mosaicism \\
\hline \multicolumn{4}{|c|}{ 1. Unrelated patients } \\
\hline 6 Males & & PM-FM & Mosaic \\
\hline 4 Males & & FM & - \\
\hline 2 Females & & 2.8-5.2-PM & - \\
\hline 1 Female & & 2.8-5.2-FM & - \\
\hline 1 Female & & 2.8-5.2-PM-FM & Mosaic \\
\hline \multicolumn{4}{|c|}{ 2. Families-Proband } \\
\hline $\mathrm{I}$ & Patient (male) & 3.3/PM and 6-8/FM & Mosaic \\
\hline I & Mother & 2.8-5.2 and 3-5.4/PM & - \\
\hline I & Sister II-2 & $2.8-5.2$ & - \\
\hline I & Sister II-3 & 2.8-5.2 and 6/FM & - \\
\hline II & Patient (male) & 2.8-5.2 and FM & Mosaic \\
\hline II & Sister 1 & 2.8-5.2 and $\mathrm{FM}$ & - \\
\hline II & Sister 2 & 2.8-5.2 and FM & Mosaic \\
\hline III & Patient (male) & FM & Mosaic \\
\hline III & Mother & 2.8-5.2 and $\mathrm{FM}$ & - \\
\hline III & Father & 2.8 & - \\
\hline III & Sister 1 & 2.8 and $\mathrm{FM}$ & Mosaic \\
\hline III & Sister 2 & $2.8-5.2$ & - \\
\hline IV & Patient 1 (male) & FM & - \\
\hline IV & Patient 2 (male) & FM & - \\
\hline IV & Mother & 2.8-5.2 and PM & - \\
\hline IV & Brother & 2.8 & - \\
\hline $\mathrm{V}$ & Patient (male) & PM & - \\
\hline $\mathrm{V}$ & Sister & 2.8-5.2 and $F M$ & - \\
\hline VI & Patient's sister & FM & - \\
\hline VI & Sister & 2.8 and $\mathrm{FM}$ & - \\
\hline VII & Patient (female) & 2.8-5.2 and $\mathrm{PM}$ & - \\
\hline VII & Mother & 2.8-5.2 and $\mathrm{PM}$ & - \\
\hline VIII & Patient (male) & FM & Mosaic \\
\hline VIII & Sister & 2.8-5.2 and FM & - \\
\hline
\end{tabular}

PM: premutation; FM: full mutation; 2.8 and 5.2: molecular weight in $\mathrm{Kb}$.

because of a high molecular weight allele not to be amplified by PCR, and in other new samples, Southern blots were performed. A total of 240 samples from unrelated individuals and 45 samples from 17 families were analyzed.

Unrelated individuals. Ten out of 172 males and 4 out of 68 females $(6 \%$ of total) showed an altered Southern blot band pattern, compatible with a premutation $(2.9-3.4 \mathrm{~Kb}$ for females and males, 5.3-5.7 Kb for females) or a full mutation (5.8- $>8 \mathrm{~Kb}$ ) (Table 1). Fifty percent (7 out of 14) of the patients presented a mosaic-pattern: i) Six males showed a premutation-full mutation mosaic pattern; ii) One female yielded a mosaic normal-premutation / normal-full mutation.

Families. When the 17 families with several at risk individuals were analyzed, 8 families (47\%) were identified with members having a Fragile $\mathrm{X}$ syndrome band pattern.
Family I. PCR results showed that the mother was a carrier of a premutation (Fig. 3b, $500 \mathrm{bp}$-fragments). The symptomatic proband DNA sample was not amplified, and thus he could be a carrier of a full mutation. Both sisters showed a unique band of $310 \mathrm{bp}$ (normal allele size), suggesting homozygosis, but heterozygosis because of a full mutation cannot be ruled out, thus, a Southern blot assay was carried out (Fig. 3c). The mother showed the typical Fragile-X-premutation carrier band pattern: 2.8 and $5.2 \mathrm{~Kb}$ bands denoted normal alleles of active and inactive $\mathrm{X}$ chromosome respectively, whereas 3 and 5.4 $\mathrm{Kb}$ bands indicated premutated alleles of the active and inactive X-chromosome. Therefore, the PCR results were confirmed in this case.

The absence of the $2.8 \mathrm{~Kb}$ fragment and the presence of higher molecular-weight-bands in the patient denoted the presence of a premutation $(3.3 \mathrm{~Kb})$ and different full mutations ( 6 and $8 \mathrm{~Kb}$ ), characteristic of a mosaic pattern. 
One sister (II-2) showed a pattern compatible with a normal female. Thus, she could be excluded from FXS-carrier risk. The other sister (II-3) presented an altered pattern. The 2.8 and $5.2 \mathrm{~Kb}$ bands, denotes a normal $\mathrm{X}$, and the $6 \mathrm{~Kb}$ band indicates a full mutation. Thus, she was diagnosed as a FXScarrier, and therefore, the status of mutation-carrier was confirmed in the mother and II-3, and excluded in II-2.

Family II. The affected male presented a Southern-pattern compatible with that of a female. Karyotype analysis revealed the presence of two $\mathrm{X}$ and one $\mathrm{Y}$ chromosomes (XXY), characteristic of Klinefelter syndrome. This data enabled us to better understand the presence of 2.8 and $5.2 \mathrm{~Kb}$ bands in the patient; in addition, full mutation bands were observed. Both sisters as a result were full mutation carriers. A full mutation mosaic pattern was observed in the patient and in sister 2 .

Family III: The patient, his mother and one of his sisters (1) carried a full mutation, which showed a mosaic pattern in the patient and his sister. The mother's DNA presented a very weak $5.2 \mathrm{~Kb}$ band suggesting that a high proportion of normal $\mathrm{X}$ chromosome would be active. The remaining sister (2) was excluded from carrier-risk.

Family IV: The two affected males of this family were full mutation carriers. The mother's DNA showed the presence of a premutation thereby confirming her carrier status while a younger brother presented a normal X chromosome $(2.8 \mathrm{~Kb})$.

Family V: The patient's DNA showed a premutation, whereas his sister carried a full mutation.

Family VI: The patient and his sister were full mutation carriers.

Family VII: Both mother and sister showed the presence of a premutation confirming their FXS-carrier status.

Family VIII: The patient was a full mutation mosaic carrier as well as his sister.

Our results enabled us to confirm the FXS-carrier status in 12 females and exclude from risk 2 others. The mothers of the patients were obligate carriers in all of these familes. All female carriers are candidates for a prenatal diagnosis during their pregnancy. None of the affected males (except family 2) showed a $2.8 \mathrm{~Kb}$-band of normal active $\mathrm{X}$ chromosome. A mosaic pattern was observed in 5 out of 20 individuals tested $(25 \%)$, members of 4 families.

\section{Discussion}

The usefulness of PCR as a diagnostic method was restricted to prescreening for normal alleles and for this reason the characterization of mutations was performed by Southern blot assay, a method that can identify all the expanded fragments including premutations and full mutations.

Mutated FMR-1 alleles were detected in $47 \%$ of at risk individuals from familial cases, but only at a low percentage $(6 \%)$ of sporadic FXS patients which may be due to alack of certainty in the clinical diagnosis. Moreover, a normal Southern-pattern does not imply an absence of Fragile-X
Syndrome. Although the main causes of FXS are expansions of (CGG)n repeats, other mutations may also generate FXS (Wohrle et al., 1992; Gedeon et al., 1992; De Boulle et al., 1993; Feng et al., 1997).

Fifty percent of unrelated individuals and $25 \%$ of familial cases showed a mosaic pattern by Southern blot as reported previously (12-41\%; Dobkin et al., 1996), and may be due to germ line and somatic instability of the (CGG)n repeats (Reyniers et al., 1999; Taylor et al., 1999). These patients may have a milder phenotype compared to those with a full mutation (Cohen et al., 1996).

In familial cases where a mutation was found, the FXS clinical diagnosis of the proband was confirmed, thereby allowing the carrier status determination of all females.

The molecular study of family 1 enabled us to analyze the expansion of the (CGG)n repeats from one generation to another. The mother was a carrier of a premutation, and transmitted to her son the premutated allele even more expanded but still in a PM range (X-chromosome still active). The full mutation in this patient would result from the subsequent expansion of the premutation in early embryogenesis because the patient showed a mosaic pattern. These results suggest that the expansion of (CGG)n may occur during different DNA metabolic activities and not only in a meiotic recombination, but also in DNA replication and repair (Pearson, 2003). One sister inherited from her mother an Xchromosome with a full mutation. The premutation band was not observed in this sister, suggesting the occurrence of a meiotic expansion to full mutation in germinal cells of her mother. This full mutation then remained stable in successive mitotic embryonic divisions (Malter et al., 1997; Moutou et al., 1997). It is important to note, however, that the analysis of leukocyte-DNA may not be representative of all other tissues (Reyniers et al., 1999; Taylor et al., 1999), although strong similarities of the FMR1 mutation in multiple tissues was also reported (Tassone et al., 1999).

The molecular mechanism of microsatellite expansion leading to Fragile-X Syndrome has generated several questions. It is presently assumed that the expansion from premutation to full mutation always occurs in the female (Pearson et al., 2005), but it has not yet been determined whether this expansion is pre or postzygotic (Pearson, 2003). From the analysis of family 1 we can hypothesize that both mechanisms are possible. The patient showed a mosaic pattern with both premutated and mutated alleles, the premutation was inherited from his mother while the expansion to full mutation might have occurred as a postzygotic process during early embryogenesis. Nevertheless, in the sister carrier of a full mutation, the expansion might have occurred as a prezygotic process in a maternal germ line meiosis.

Family 5 showed a disagreement between the premutation found and the phenotype expressed by the patient. The presence of a premutation suggests that the X-chromosome is unmethylated and active so no mental retardation is expected. However, in some cases this mutation leads to a different 
phenotype in males, named Fragile-X tremor/ataxia syndrome (Hagerman et al., 2001). The reason for this disagreement may be due to the following: i) In other tissues (e.g. the CNS), the premutation may expand to full mutation; ii) The hypermethylation itself may not be responsible for the inactivation of the premutated allele.

An early diagnosis is essential for individuals born with the syndrome. An accurate diagnose of FXS allows subsequent and more correct genetic counseling to help answer the concerns of the family. Women with detected premutations or full mutations can request prenatal diagnostic and genetic counsel before or during their pregnancy. The molecular studies that we have carried out on the FMR-1 gene have great relevance, especially when taking into account that early diagnosis contributes to improved quality of life for the patients and their families.

Acknowledgments The authors are grateful to the families with FXS-patients and to the medical staff of the Hospitals for their collaboration. The authors have no conflicts of interest directly related to the content and conduct of this study. This work was supported by grants from Universidad de Buenos Aires (B068) and CONICET PIP 2000, No 02057

\section{References}

Abitbol, M., Menini, C., Delezoide, A. L., Rhyner, T., Vekemans, M. and Mallet, J. (1993) Nucleus basalis magnocellularis and hippocampus are the major sites of FMR-1 expression in the human fetal brain. Nat Genet. 4, 147-153.

Allingham-Hawkins, D. J., Brown, C. A., Babul, R., Chitayat, D., Krekewich, K., Humphries, Ray, P. N. and Teshima, I. E. (1996) Tissue-specific methylation differences and cognitive function in fragile X premutation females. Am. J. Med. Genet. 64, 329-333.

Bear, M. F., Huber, K. M. and Warren, S. T. (2004) The mGluR theory of fragile X mental retardation. Trends Neurosci. 27, 370-377.

Coffee, B., Zhang, F., Warren, S. T. and Reines, D. (1999) Acetylated histones are associated with FMR1 in normal but not fragile X-syndrome cells. Nature Genet. 22, 98-101.

Cohen, I. L., Nolin, S. L., Sudhalter, V., Ding, X. H., Dobkin, C. S. and Brown, W. T. (1996) Mosaicism for the FMR1 gene influences adaptive skills development in fragile $\mathrm{X}$-affected males. Am. J. Med. Genet. 64, 365-369.

Corbin, F., Bouillon, M., Fortin, A., Morin, S., Rousseau, F. and Khandjian, E. W. (1997) The fragile X mental retardation protein is associated with poly $(\mathrm{A})^{+}$mRNA in actively translating polyribosomes. Hum. Mol. Genet. 8, 1465-1472.

De Boulle, K., Verkerk, A. J., Reyniers, E., Vits, L., Hendrickx, J., Van Roy, B., Den Bos, F. V., Graaff, E., Oostra, B. A. and Willems, P. J. (1993) A point mutation in the FMR-1 gene associated with fragile X mental retardation. Nature Genet. 3, 31-35.

Dobkin, C. S., Nolin, S. L., Cohen, I., Sudhalter, V., Bialer, M. G., Ding, X. H. Jenkins, E. C., Zhong, N. and Brown, W. T. (1996) Tissue differences in fragile $X$ mosaics: mosaicism in blood cells may differ greatly from skin. Am. J. Med. Genet. 64, 296-301.

Feng, Y., Absher, D., Eberhart, D. E., Brown, V., Malter, H. E. and Warren, S. T. (1997) FMRP associates with polyribosomes as an $\mathrm{mRNP}$ and the I304N mutation of severe fragile $\mathrm{X}$ syndrome abolishes this association. Mol. Cell. 1, 109-118.

Gedeon, A. K., Baker, E., Robinson, H., Partington, M. W., Gross, B., Manca, A., Korn, B., Poustka, A., Yu, S., Sutherl, G. R. and Mulley, J. C. (1992) Fragile X syndrome without CCG amplification has an FMR1 deletion. Nature Genet. 1, 341-344.

Genc, B., Muller-Hartmann, H., Zeschinig, M., Deissler, H., Schimtz, B., Majewski, F., Gontard, A. and Doerfler, W. (2000) Methylation mosaicism of 5'-(CGG)(n)-3' repeats in fragile $\mathrm{X}$, premutation and normal individuals. Nucleic Acids Res. 28, 2141-2152.

Hagerman, R. J., Leehey, M., Heinrichs, W., Tassone, F., Wilson, R., Hills, J., Grigsby, J., Gage, B. and Hagerman, P. J. (2001) Intention tremor, parkinsonism and generalized brain atrophy in males carriers of fragile X. Neurology 57, 127-130.

Hilbert, P. and Sabine, M. (1996) Variation of CGG repeats at the fragil X site: clear signal enhancement using expand TM long template. Biochemica, 4, 29.

Hinds, H. L., Ashley, C. T., Sutcliffe, J. S., Nelson, D. L., Warren, S. T., Housman, D. E. and Schalling, M. (1993) Tissue specific expression of FMR-1 provides evidence for a functional role in fragile X syndrome. Nat. Genet. 3, 36-43.

Kremer, E. J., Pritchard, M., Lynch, M., Yu, S., Holman, K., Baker, E., Warren, S. T., Schlessinger, D., Sutherland, G. R. and Richards, R. I. (1991) Mapping of DNA instability at the fragile $\mathrm{X}$ to a trinucleotide repeat sequence $\mathrm{p}(\mathrm{CCG}) \mathrm{n}$. Science 252, 1711-1714.

Laggerbauer, B., Ostareck, D., Keidel, E. M., Ostareck-Lederer, A. and Fischer, U. (2001) Evidence that fragile $\mathrm{X}$ mental retardation protein is a negative regulator of translation. Hum. Mol. Genet. 10, 329-338.

Li, Z., Zhang, Y., Ku, L., Wilkinson, K. D., Warren, S. T. and Feng, Y. (2001) The fragile $\mathrm{X}$ mental retardation protein inhibits translation via interacting with mRNA. Nucleic Acids Res. 29, 2276-2283.

Malter, H. E., Iber, J. C., Willemsen, R., de Graaff, E., Tarleton, J. C., Leisti, J., Warren, S. T. and Oostra, B. A. (1997) Characterization of the full fragile $\mathrm{X}$ syndrome mutation in fetal gamets. Nature Genet. 15, 165-169.

Merenstein, S. A., Sobesky, W. E., Taylor, A. K., Riddle, J. E., Tran, H. X. and Hagerman R. J. (1996) Molecular-clinical correlations in males with an expanded FMR1 mutation. Am. $J$. Med. Genet. 64, 388-394.

Moutou, C., Vincent, M. C., Blancalena, V. and Mandel, J. L. (1997) Transition from premutation to full mutation in fragile $\mathrm{X}$ sydrome is likely to be prezygotic. Hum. Mol. Genet. 6, 971-979.

Oberlé, I., Ruosseau, F., Heitz, D., Kretz, C., Devys, D., Hanauer, A., Boue, J., Bertheas, M. F. and Mandel, J. L. (1991) Instability of a 550-base pair DNA segment and abnormal methylation en fragil X syndrome. Science 252, 1097-1102.

Pearson, C. E. (2003) Slipping while slipping? Trinucleotide repeat expansions in germ cells. Trends Mol Med. 9, 490-495.

Pearson, C. E., Edamura, K. N. and Cleary, J. D. (2005) Repeat instability: mechanisms of dynamic mutations. Nature Rev. Genet. 6, 729-742. 
Pieretti, M., Zheng, F., Fu, Y. H., Warren, S. T., Oostra, B. A., Caskey, C. T. and Nelson, D. L. (1991) Absence of expression of the FMR-1 gene in fragile X syndrome. Cell 66, 817-822.

Reyniers, E., Martin, J. J., Cras, P., Van Marck, E., Handig, I., Jorens, H. Z., Oostra, B. A., Kooy, R. F. and Willems, P. J. (1999) Postmortem examination of two fragile X brothers with an FMR1 full mutation. Am. J. Med. Genet. 84, 245-249.

Sherman, S. L., Jacobs, P. A., Morton, N. E., Froster-Iskenius. U., Howard-Peebles, P. N., Nielsen, K. B., Partington, M. W., Sutherland, G. R., Turner, G. and Watson, M. (1985) Further segregation analysis of the fragile $\mathrm{X}$ syndrome with special reference to transmitting males. Hum. Genet. 69, 289-299.

Tassone, F., Hagerman, R. J., Gane, L. W. and Taylor, A. K. (1999) Strong similarities of the FMR1 mutation in multiple tissues; postmortem studies of a male with a full mutation and a male carrier of a premutation. Am. J. Med. Genet. 84, 240244.

Taylor, A. K., Tassone, F., Dyer, P. N., Hersch, S. M., Harris, J.
B., Greenough, W. T. and Hagerman, R. J. (1999) Tissue heterogeneity of the FMR1 mutation in a high-functioning male with fragile X syndrome. Am. J. Med. Genet. 84, 233239.

Verkerk, A. J. M. H., Graaff, E., De Boulle, K., Eichler, E.E., Konecki, D.S., Reyniers, E. et al. (1991) Identification of a gene (FMR-1) containing a CCG repeat coincident with a fragile $\mathrm{X}$ break point cluster region exhibing lengh variation in fragile X syndrome. Cell $\mathbf{6 5}, 905-914$.

Warren, S. T. and Sherman, S. L. (2001) The fragile X syndrome; in The Metabolic and Molecular Basis of Inherited Disease, Saiver, C. R., Beaudet, A. L., Sly, W. S. and Valle, D. (eds.), pp. 1257-1289, Mc Graw Hill, New York, USA.

Wohrle, D., Kotzot, D., Hirst, M. C., Manca, A., Korn, B., Schmidt, A. et al. (1992) A microdeletion of less than $250 \mathrm{~kb}$, including the proximal part of the FMR-1 gene and the fragile$\mathrm{X}$ site, in a male with the clinical phenotype of fragile- $\mathrm{X}$ syndrome. Am. J. Hum. Genet. 51, 299-306. 